\title{
ADAPTASI SPASIAL PADA INTERIOR RUMAH TINGGAL PASCA GEMPA DI KASONGAN, BANTUL
}

\author{
Martino Dwi Nugroho* \\ Program Studi Desain Interior, Fakultas Seni Rupa, Institut Seni Indonesia Yogyakarta
}

May 27, 2006, was a somber day for the people living ini Yogyakarta and Central Java Provinces. Sub-province of Bantul was the most severely hit by the earthquake happening early in the morning. Around 7.057 houses were sacked, including the craft village of Kasongan. Most Kasongan families now live in houses made avalaible by domestic and foreign aids. They have lived in the new houses for two years. During this time, they have to make adjusments to the new environment. This research is intended to observe how families living at the village of Kajen, Kasongan, make adjustments and adapt to the new conditions living in new houses supplied through aids. This village is purposely chosen as the sample. The result of the investigation indicates that people of this village has to return the heat during the day, doing activities by using multi-purpose space and furniture.

\section{Keywords : interior, adaptation, adjustment.}

Hari Sabtu, tanggal 27 Mei 2006 merupakan hari yang suram bagi masyarakat Daerah Istimewa Yogyakarta dan sebagian Jawa Tengah. Saat itu, gempa bumi tektonik dengan kekuatan 5,9 pada skala Richter berlangsung kurang lebih pukul 05.55 WIB selama 57 detik mengguncang wilayah tersebut. Ribuan nyawa melayang, harta benda hilang dan banyak orang kehilangan pekerjaan. Tak terkecuali rumah. Ratusan rumah rusak bahkan hancur sehingga banyak warga kehilangan tempat tinggal.

Kabupaten Bantul merupakan daerah yang paling parah terkena bencana. Informasi menyebutkan sebanyak 7.057 rumah di daerah ini rubuh. Salah satu sentra wisata yang terkena dampak gempa cukup parah adalah Kasongan. Salah satu bantuan yang diterima oleh warga Kasongan adalah rumah atau tempat tinggal. Saat ini mereka sudah menempati rumah bantuan tersebut hampir dua tahun. Selama waktu tersebut mereka mengalami penyesuaian terhadap lingkungan yang baru. Penyesuaian diri ini mengakibatkan perubahan pada diri seseorang tersebut atau seseorang akan merubah lingkungan huniannya sesuai dengan kebutuhannya. Perubahan tersebut dapat disebabkan karena tempat maupun lingkungan dari tempat tinggal sebelumnya. Menurut Sarwono (1992:48), kelebihan manusia dari makhluk hidup lainnya, adalah bahwa ia bisa mengubah kemanfaatan dari suatu stimulus sehingga dapat lebih memenuhi kebutuhannya sendiri. Tekanantekanan meningkatkan energi dalam dirinya sehingga ia harus mengadakan penyesuaian diri (coping behavior) atau menyesuaikan lingkungan untuk kondisi dirinya. Penyesuaian antara individu dengan lingkungan disebut adaptasi dan bila ada penyesuaian keadaan lingkungan untuk dirinya secara individu dinamai adjustment. Selanjutnya menurut Sarwono (1992:107109), seseorang akan mempersepsikan lingkungannya kemungkinan melalui dua macam. Kemungkinan yang pertama adalah rangsangan-rangsangan yang dipersepsikan

*Korespondensi penulis dialamatkan ke Program Studi Desain Interior, Fakultas Seni Rupa, Institut Seni Indonesia Yogyakarta, Telp/Fax: +62 274417219 e-mail: tino_di@yahoo.com 
itu akan berada dalam batas-batas normal sehingga timbullah kondisi seimbang (homeostatis). Kemungkinan kedua adalah rangsangan-rangsangan itu berada di atas batas-batas optimal (overstimulation). Akibat kemungkinan yang kedua ini adalah stres dan manusia harus melakukan penyesuaian diri (coping behaviour).

Biasanya untuk mencapai kepuasan yang lebih tinggi pemakai ruang mengadakan modifikasi spasial sesuai dengan kebutuhan (Hester, 1975;Lang, 1974). Kepuasan pemakai ruang terutama dapat dinilai dari kesumpekan, suasana ruang terutama estetikanya yang di dapat lewat penampilan visual dan faktor sensori, simbol kepemilikan, ukuran serta bentuk ruang, tatanan furnitur dan aspek spasial, pencahayaan dan penghawaan (Heimstra, 1974; Porteous, 1977; Ching, 1987). Menurut Sarwono (1992:108-111), adaptasi adalah mengubah tingkah laku agar sesuai dengan lingkungan. Sebagai contoh pengemudi kendaraan membelokkan kendaraannya untuk menghindari lubang-lubang di jalan, sedangkan adjustment adalah mengubah lingkungan agar sesuai dengan tingkah laku. Lokasi Kasongan dipilih karena rumah masyarakat di Kasongan memiliki dua fungsi yaitu sebagai rumah tinggal dan tempat bekerja. Hal ini disebabkan oleh karena sebagian besar masyarakat Kasongan adalah perajin gerabah. Sehingga menarik untuk diteliti bagiamana kejelasan hubungan antara penyesuaian lingkungan, kebutuhan penghuni dan perilaku ditinjau dari aspek adaptasi dan adjustment pada setting yang baru, dalam hal ini rumah tinggal yang baru terkait dengan aktifitas mereka dalam memfungsikan dan menata ruang, baik sebagai rumah tinggal maupun tempat bekerja.

\section{BAHAN DAN METODE}

Jenis penelitian ini adalah penelitian kualitatif dengan pendekatan deskriptif analitik. Populasi penelitian ada di dukuh Kajen Kasongan dengan sampel RT 03 dan RT 04 yang ditentukan dengan menggunakan teknik purposive sampling. Metoda analisis dengan cara verifikasi, dianalisis secara deskripsi kualitatif sehingga diperoleh informasi tentang adaptasi penghuni akibat perubahan seting dalam hal penataan perabot, aktifitas dan tata kondisional. Bentuk data yang akan diambil dan pengolahannya berupa data kualitatif. Kemudian temuantemuan tersebut diinterpretasikan menuju suatu kesimpulan peneliti.

\section{Tinjauan Tentang Kasongan}

Kasongan adalah nama daerah tujuan wisata di wilayah kabupaten Bantul, Daerah Istimewa Yogyakarta yang terkenal karena hasil kerajinan gerabahnya. Tempat ini tepatnya terletak di daerah pedukuhan Kajen, desa Bangunjiwo, kecamatan Kasihan, Bantul, Daerah Istimewa Yogyakarta, ( S $7.846567^{\circ}-\mathrm{E} 110.344468^{\circ}$ ) sekitar $6 \mathrm{~km}$ dari Alun-alun Utara Yogyakarta ke arah Selatan.

Kasongan adalah salah satu nama wilayah desa pedukuhan Kajen, Kelurahan Bangunjiwo Kecamatan Kasihan Bantul yang sebagian besar penduduknya bermatapencaharian sebagai perajin keramik. Wilayah desa itu cukup kecil tetapi dikenal kalangan luas berkat potensi kerajinan keramiknya yang unik.Kegiatan pembelajaran yang selama ini berlangsung, yang berpijak pada teori behavioristik, banyak didominasi oleh pengajar. Pengajar menyampaikan materi pembelajaran melalui ceramah, dengan harapan peserta didik dapat memahaminya dan memberikan respon sesuai dengan materi yang diceramahkan. Dalam proses pembelajaran, pengajar banyak menggantungkan materi ajarnya pada buku-buku teks. Untuk

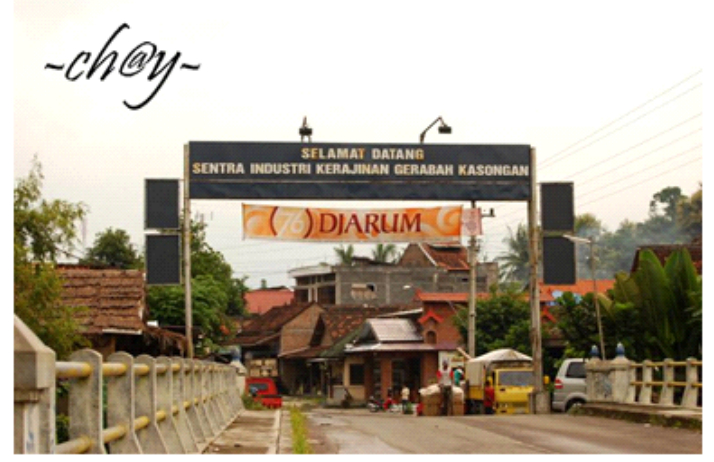

Gambar 1. Gerbang ke Sentra Industri Kasongan 
mempermudah proses berlangsungnya pembelajaran, seringkali materi yang disampaikan oleh pengajar menyesuaikan dengan urutan isi buku teks yang menjadi buku acuan.

Berdasarkan cerita lisan yang berhasil dihimpun, nama Kasongan berhubungan erat dengan nama Kyai Song yang dianggap sebagai cikal bakal desa Kasongan (Gustami, 1985:19). Nama itu tampaknya ada hubungannya dengan tokoh Kyai Guru Kasongan yang bernama Ngabdur Raupi, seorang prajurit Pangeran Diponegoro yang meninggal di medan laga ketika melawan serdadu Belanda dalam upaya mempertahankan pesanggrahan Diponegoro di Gua Selarong. Sampai saat ini peninggalan berupa makam yang disebut makam Kyai Kasongan di wilayah itu masih dikeramatkan oleh masyarakat sekitar.

Sejak tahun 1971-1972, Desa Wisata Kasongan mengalami kemajuan cukup pesat. Sapto Hudoyo (seorang seniman besar Yogyakarta) membantu mengembangkan Desa Wisata Kasongan dengan membina masyarakatnya yang sebagian besar pengrajin untuk memberikan berbagai sentuhan seni dan komersil bagi desain kerajinan gerabah sehingga gerabah yang dihasilkan tidak menimbulkan kesan yang membosankan dan monoton, namun dapat memberikan nilai seni dan nilai ekonomi yang tinggi. Keramik Kasongan dikomersilkan dalam skala besar oleh Sahid Keramik sekitar $\mathrm{t}$ a $\mathrm{h} \mathrm{u} \mathrm{n}$ 1980 a $n$ (http://id.wikipedia.org/wiki/Kasongan).

\section{HASIL DAN PEMBAHASAN}

Analisis data disajikan dalam bentuk tabel yang terdiri dari analisis adaptasi dan analisis adjustment. Sampel penelitian terdiri dari sepuluh rumah kasus (RK).

Menurut Lantrip (1993:23-24), manusia butuh lingkungan ruang yang layak huni/pakai. Layak huni umumnya merujuk pada keadaan lingkungan yang nyaman untuk dihuni dan digunakan manusia. Sebenarnya, tidak ada standar definisi layak huni, oleh karena apa yang manusia butuhkan terutama pada lingkungannya untuk dianggap layak huni (habitable) haruslah memuaskan.

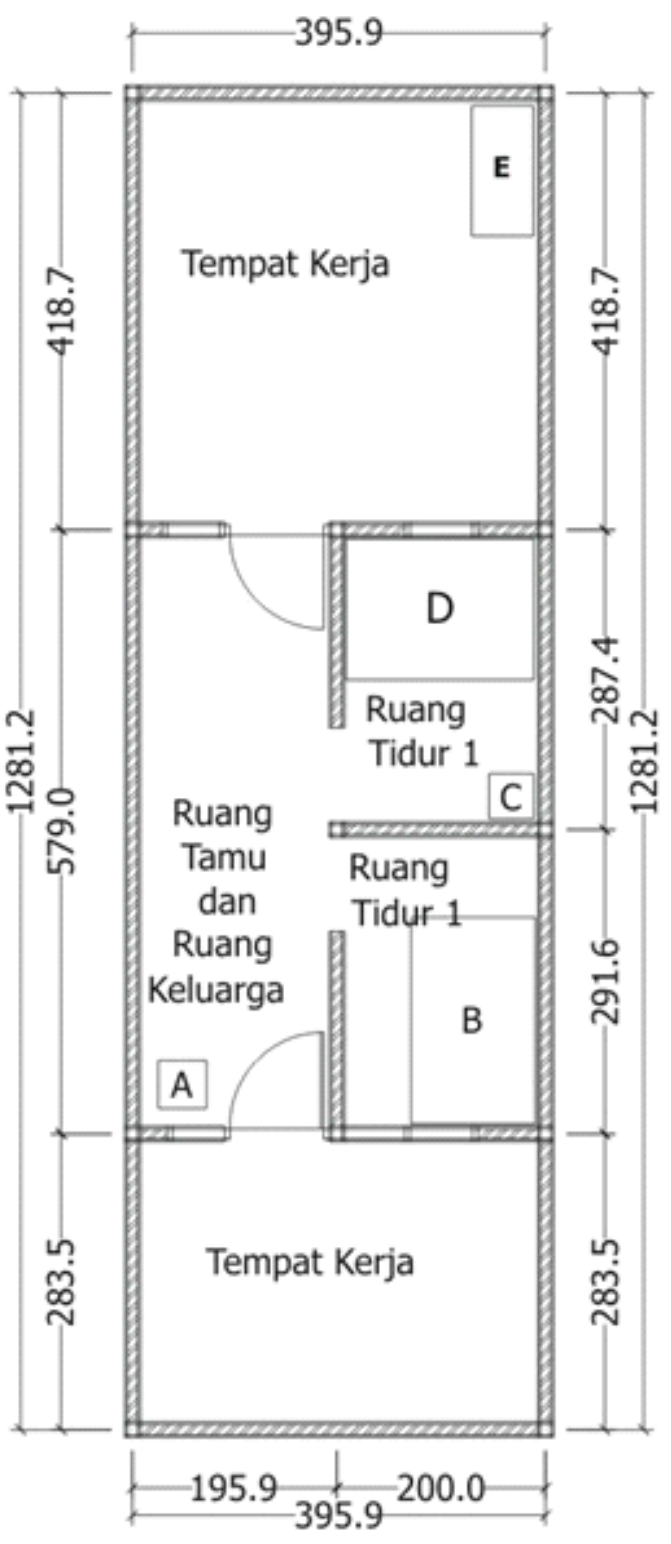

Gambar 2. Denah dan Layout salah satu Rumah Bantuan

KETERANGAN :

\begin{tabular}{|c|l|l|r|l|}
\hline NO & KODE & JENIS PERABOT & DIMENSI & BAHAN \\
\hline 1 & A & Rak TV & $46 \times 46 \times 54$ & Kayu \\
\hline 2 & B & Tempat Tidur & $198 \times 119 \times 45$ & Kayu \\
\hline 3 & C & Almari & $43 \times 43 \times 117$ & Plastik \\
\hline 4 & D & Tempat Tidur & $200 \times 135 \times 31$ & Kayu \\
\hline 5 & E & Meja & $125 \times 59 \times 69$ & Kayu \\
\hline
\end{tabular}


Tabel 1. Adaptasi

\begin{tabular}{|c|c|c|c|c|c|}
\hline $\begin{array}{l}\text { Rumah } \\
\text { Kasus }\end{array}$ & Ruang & A ktifitas & $\begin{array}{c}\text { Penataan } \\
\text { Perabot } \\
(\text { perilaku })\end{array}$ & $\begin{array}{c}\text { Penghawaan } \\
\text { (perilaku })\end{array}$ & $\begin{array}{c}\text { Pencahay aan } \\
(\text { perilaku })\end{array}$ \\
\hline \multirow[t]{4}{*}{$\begin{array}{ll}\text { RK } 1 \\
\end{array}$} & $\begin{array}{l}\text { Ruang } \\
\text { Tamu \& } \\
\text { Ruang } \\
\text { Keluarga } \\
\end{array}$ & $\begin{array}{l}\text { Menerima } \\
\text { Tamu dan } \\
\text { Menonton } \\
\text { TV. }\end{array}$ & & $\begin{array}{l}\text { Melepas baju } \\
\text { (laki-laki), }\end{array}$ & Tidak ada. \\
\hline & $\begin{array}{l}\text { Ruang } \\
\text { Tidur }\end{array}$ & $\begin{array}{l}\text { Tidur, } \\
\text { Istirahat }\end{array}$ & $\begin{array}{ll}\mathrm{Di} & \text { bawah } \\
\text { (tanpa } & \text { tempat } \\
\text { tidur) } & \\
\end{array}$ & $\begin{array}{lr}\text { Tidur di } & \text { dekat } \\
\text { pintu } & \text { atau } \\
\text { jendela } & \\
\end{array}$ & Tidak ada \\
\hline & Dapur & $\begin{array}{l}\text { Memasak, } \\
\text { membuat } \\
\text { minuman }\end{array}$ & $\begin{array}{l}\text { Duduk } \\
\text { dingklik atau } \\
\text { jongkok, } \\
\text { berdiri. }\end{array}$ & Tidak ada & $\begin{array}{l}\text { Meracik } \\
\text { bumbu dekat } \\
\text { pintu. }\end{array}$ \\
\hline & $\begin{array}{l}\text { Tempat } \\
\text { Kerja }\end{array}$ & $\begin{array}{l}\text { Membuat } \\
\text { keramik }\end{array}$ & $\begin{array}{l}\text { Duduk } \\
\text { dingklik }\end{array}$ & $\begin{array}{l}\text { Melepas baju } \\
\text { (anak laki- } \\
\text { laki), kadang- } \\
\text { kadang duduk } \\
\text { di dekat pintu }\end{array}$ & Tidak ada \\
\hline \multirow[t]{4}{*}{ RK 2} & $\begin{array}{l}\text { Ruang } \\
\text { Tamu \& } \\
\text { Ruang } \\
\text { Keluarga }\end{array}$ & $\begin{array}{l}\text { - Ruang } \\
\text { tamu : } \\
\text { Menyimpa } \\
\text { n } \\
\text { peralatan, } \\
\text { gudang } \\
\text { - Ruang } \\
\text { keluarga : } \\
\text { menonton } \\
\text { TV, Tidur. }\end{array}$ & Tidak ada & $\begin{array}{l}\text { Melepas baju } \\
\text { pada saat tidur } \\
\text { atau menonton } \\
\text { TV }\end{array}$ & Tidak ada \\
\hline & $\begin{array}{l}\text { Ruang } \\
\text { Tidur }\end{array}$ & $\begin{array}{l}\text { Tidur, } \\
\text { tempat } \\
\text { menyimpan } \\
\text { pakaian } \\
\text { yang sudah } \\
\text { kering dan } \\
\text { siap } \\
\text { disetrika }\end{array}$ & $\begin{array}{l}\mathrm{Di} \text { tempat } \\
\text { tidur, di tikar }\end{array}$ & $\begin{array}{l}\text { Membuka } \\
\text { pintu, } \\
\text { menggunakan } \\
\text { kaos dalam, } \\
\text { telanjang dada } \\
\text { (laki-laki) }\end{array}$ & Tidak ada \\
\hline & Dapur & $\begin{array}{l}\text { Memasak, } \\
\text { mencuci } \\
\text { peralatan } \\
\text { dapur (dekat } \\
\text { dengan } \\
\text { sumur) }\end{array}$ & Jongkok. & Tidak ada & Tidak ada \\
\hline & $\begin{array}{l}\text { Tempat } \\
\text { Kerja }\end{array}$ & $\begin{array}{l}\text { Membuat } \\
\text { keramik, } \\
\text { menerima } \\
\text { tamu }\end{array}$ & $\begin{array}{l}\text { Duduk } \\
\text { bangku } \\
\text { saat menerima } \\
\text { tamu, duduk } \\
\text { di } \\
\text { pada }\end{array}$ & $\begin{array}{l}\text { Melepas baju } \\
\text { atau memakai } \\
\text { kaos dalam } \\
\text { bagi bapak. }\end{array}$ & Tidak ada \\
\hline
\end{tabular}




\begin{tabular}{|c|c|c|c|c|c|}
\hline $\begin{array}{l}\text { Rumah } \\
\text { Kasus }\end{array}$ & Ruang & Aktifitas & $\begin{array}{c}\text { Penataan } \\
\text { Perabot } \\
\text { (perilaku) } \\
\end{array}$ & $\begin{array}{c}\text { Penghawaan } \\
\text { (perilaku) }\end{array}$ & $\begin{array}{c}\text { Pencahayaan } \\
\text { (perilaku) }\end{array}$ \\
\hline \multirow[t]{4}{*}{ RK 3} & $\begin{array}{l}\text { Ruang } \\
\text { Tamu \& } \\
\text { Ruang } \\
\text { Keluarga }\end{array}$ & \begin{tabular}{lr}
\multicolumn{2}{l}{ Menerima } \\
tamu dan \\
tidur di \\
amben
\end{tabular} & $\begin{array}{l}\text { Tidur diatas } \\
\text { amben, duduk } \\
\text { di atas amben }\end{array}$ & $\begin{array}{l}\text { Melepas } \\
\text { pakaian (laki- } \\
\text { laki), ngisis di } \\
\text { teras/tempt } \\
\text { kerja. }\end{array}$ & Tidak ada \\
\hline & $\begin{array}{l}\text { Ruang } \\
\text { Tidur } \\
\end{array}$ & $\begin{array}{l}\text { Tidur, } \\
\text { istirahat }\end{array}$ & \begin{tabular}{|l|} 
Tidur di atas \\
tempat tidur \\
\end{tabular} & $\begin{array}{l}\text { Tidur di bawah } \\
\text { jendela. }\end{array}$ & Tidak ada \\
\hline & Dapur & Memasak & $\begin{array}{l}\text { Jongkok } \\
\text { (tidak ada } \\
\text { dingklik), } \\
\text { berdiri } \\
\text { (menyiapkan } \\
\text { minuman) } \\
\end{array}$ & Tidak ada & Tidak ada \\
\hline & $\begin{array}{l}\text { Tempat } \\
\text { Kerja }\end{array}$ & $\begin{array}{l}\text { Jarang, } \\
\text { bahkan tidak } \\
\text { pernah } \\
\text { digunakan }\end{array}$ & Tidak ada & Tidak ada & Tidak ada \\
\hline \multirow[t]{4}{*}{$\begin{array}{ll}\text { RK } 4 \\
\end{array}$} & $\begin{array}{l}\text { Ruang } \\
\text { Tamu \& } \\
\text { Ruang } \\
\text { Keluarga } \\
\end{array}$ & $\begin{array}{l}\text { Menerima } \\
\text { tamu, } \\
\text { menonton } \\
\text { TV. }\end{array}$ & $\begin{array}{l}\text { Dengan } \\
\text { menggelar } \\
\text { tikar, }\end{array}$ & $\begin{array}{l}\text { Membuka baju } \\
\text { bagi laki-laki, } \\
\text { pergi ke teras } \\
\text { yang lebih isis }\end{array}$ & Tidak ada \\
\hline & $\begin{array}{l}\text { Ruang } \\
\text { Tidur }\end{array}$ & $\begin{array}{l}\text { Tidur, } \\
\text { merawat } \\
\text { bayi. }\end{array}$ & $\begin{array}{l}\text { Duduk di } \\
\text { lantai saat } \\
\text { merawat bayi, } \\
\text { tidur si kasur }\end{array}$ & $\begin{array}{l}\text { Menggunakan } \\
\text { kipas, melepas } \\
\text { baju bagi laki- } \\
\text { laki. }\end{array}$ & Tidak ada \\
\hline & Dapur & $\begin{array}{l}\text { Memasak, } \\
\text { menyiapkan } \\
\text { minuman }\end{array}$ & $\begin{array}{l}\text { Jongkok saat } \\
\text { me masak, } \\
\text { berdiri saat } \\
\text { me mbuat } \\
\text { minuman }\end{array}$ & Tidak ada & Tidak ada \\
\hline & $\begin{array}{l}\text { Tempat } \\
\text { Kerja }\end{array}$ & $\begin{array}{l}\text { Membuat } \\
\text { keramik, } \\
\text { berfungsi } \\
\text { sebagai teras } \\
\text { untuk } \\
\text { ngobrol dan } \\
\text { lain-lain. }\end{array}$ & $\begin{array}{lr}\text { Duduk di } \\
\text { dingklik saat } \\
\text { me mbuat } \\
\text { keramik }\end{array}$ & Tidak ada & Tidak ada \\
\hline RK 5 & $\begin{array}{l}\text { Ruang } \\
\text { Tamu \& } \\
\text { Ruang } \\
\text { Keluarga }\end{array}$ & $\begin{array}{l}\text { Menerima } \\
\text { tamu, } \\
\text { istirahat, } \\
\text { tidur, nonton } \\
\text { TV }\end{array}$ & $\begin{array}{l}\text { Menggelar } \\
\text { tikar }\end{array}$ & $\begin{array}{l}\text { Memaki } \\
\text { pakaian yang } \\
\text { tidak } \\
\text { panas/tipis, } \\
\text { melepas baju } \\
\text { bagi laki-laki }\end{array}$ & Tidak ada \\
\hline
\end{tabular}




\begin{tabular}{|c|c|c|c|c|c|}
\hline $\begin{array}{c}\text { Rumah } \\
\text { Kasus }\end{array}$ & \multirow{2}{*}{$\begin{array}{l}\text { Ruang } \\
\text { Ruang } \\
\text { Tidur }\end{array}$} & \multirow{2}{*}{$\begin{array}{l}\text { Aktifitas } \\
\text { Tidur, } \\
\text { istirahat }\end{array}$} & \multirow{2}{*}{$\begin{array}{c}\text { Penataan } \\
\text { Perabot } \\
\text { (perilaku) }\end{array}$} & \multirow{2}{*}{$\begin{array}{l}\text { Penghawaan } \\
\text { (perilaku) } \\
\text { Tidur dekat } \\
\text { pintu, melepas } \\
\text { baju bagi laki- } \\
\text { laki. }\end{array}$} & \multirow{2}{*}{$\begin{array}{l}\text { Pencahayaan } \\
\text { (perilaku ) }\end{array}$} \\
\hline & & & & & \\
\hline & Dapur & $\begin{array}{l}\text { Memasak, } \\
\text { membuat } \\
\text { minuman }\end{array}$ & $\begin{array}{l}\text { Jongkok, } \\
\text { duduk di } \\
\text { dingklik dan } \\
\text { berdiri. }\end{array}$ & Tidak ada & Tidak ada \\
\hline & $\begin{array}{l}\text { Tempat } \\
\text { Kerja }\end{array}$ & $\begin{array}{l}\text { Membuat } \\
\text { keramik }\end{array}$ & $\begin{array}{l}\text { Duduk } \\
\text { dingklik }\end{array}$ & Tidak ada & Tidak ada \\
\hline \multirow[t]{4}{*}{ RK 6} & $\begin{array}{l}\text { Ruang } \\
\text { Tamu \& } \\
\text { Ruang } \\
\text { Keluarga }\end{array}$ & $\begin{array}{l}\text { Menerima } \\
\text { tamu, } \\
\text { menonton } \\
\text { TV, tidur, } \\
\text { istirahat }\end{array}$ & $\begin{array}{l}\text { Duduk di } \\
\text { kursi, } \\
\text { menggelar } \\
\text { tikar. }\end{array}$ & $\begin{array}{lr}\text { Duduk di } & \text { dekat } \\
\text { jendela } & \text { atau } \\
\text { pintu } & \text { yang } \\
\text { terbuka. } & \end{array}$ & Tidak ada \\
\hline & $\begin{array}{l}\text { Ruang } \\
\text { Tidur }\end{array}$ & $\begin{array}{l}\text { Tidur, } \\
\text { istirahat. }\end{array}$ & $\begin{array}{l}\text { Tidur di kasur } \\
\text { busa. }\end{array}$ & $\begin{array}{lr}\text { Tidur di } & \text { dekat } \\
\text { jendela } & \text { atau } \\
\text { dekat fan. } & \\
\end{array}$ & Tidak ada \\
\hline & Dapur & $\begin{array}{l}\text { Memasak, } \\
\text { membuat } \\
\text { minuman }\end{array}$ & Berdiri. & Tidak ada & Tidak ada \\
\hline & $\begin{array}{l}\text { Tempat } \\
\text { Kerja }\end{array}$ & $\begin{array}{l}\text { Membuat } \\
\text { keramik }\end{array}$ & $\begin{array}{ll}\text { Duduk } & \text { di } \\
\text { dingklik } & \\
\end{array}$ & Tidak ada & Tidak ada \\
\hline \multirow[t]{4}{*}{ RK 7} & $\begin{array}{l}\text { Ruang } \\
\text { Tamu \& } \\
\text { Ruang } \\
\text { Keluarga }\end{array}$ & $\begin{array}{l}\text { Menerima } \\
\text { tamu, } \\
\text { menonton } \\
\text { TV }\end{array}$ & $\begin{array}{l}\text { Duduk } \text { di } \\
\text { kursi, tiduran } \\
\text { di lantai atau } \\
\text { di tempat } \\
\text { tidur. }\end{array}$ & $\begin{array}{l}\text { Membuka } \\
\text { pintu dan } \\
\text { jendela selebar- } \\
\text { lebarnya, } \\
\text { duduk di dekat } \\
\text { pintu dan } \\
\text { jendela. }\end{array}$ & Tidak ada \\
\hline & $\begin{array}{l}\text { Ruang } \\
\text { Tidur }\end{array}$ & $\begin{array}{l}\text { Tidur, } \\
\text { istirahat }\end{array}$ & $\begin{array}{l}\text { Di kasur busa } \\
\text { tanpa tempat } \\
\text { tidur ( ruang } \\
\text { tidur } \\
\text { menggunakan } \\
\text { tempat tidur } \\
\text { (tempat tidur } \\
\text { 1) }\end{array}$ & $\begin{array}{l}\text { Membuka } \\
\text { jendela dan } \\
\text { pintu dan tidur } \\
\text { di dekatnya. }\end{array}$ & Tidak ada \\
\hline & Dapur & $\begin{array}{l}\text { Memasak, } \\
\text { membuat } \\
\text { minuman }\end{array}$ & $\begin{array}{lr}\text { Duduk } & \text { di } \\
\text { dingklik } & \text { saat } \\
\text { meracik } & \text { dan } \\
\text { berdiri } & \text { saat } \\
\text { memasak. } & \end{array}$ & $\begin{array}{l}\text { Memkai } \\
\text { pakaian tipis, } \\
\text { memakai } \\
\text { pakaian dalam } \\
\text { wanita (tanpa } \\
\text { kebaya) }\end{array}$ & Tidak ada \\
\hline & $\begin{array}{l}\text { Tempat } \\
\text { Kerja }\end{array}$ & $\begin{array}{l}\text { Membuat } \\
\text { keramik }\end{array}$ & $\begin{array}{l}\text { Duduk } \quad \mathrm{di} \\
\text { dingklik }\end{array}$ & $\begin{array}{l}\text { Tidak memakai } \\
\text { baju (untuk }\end{array}$ & Tidak ada \\
\hline
\end{tabular}




\begin{tabular}{|c|c|c|c|c|c|}
\hline $\begin{array}{l}\text { Rumah } \\
\text { Kasus }\end{array}$ & Ru ang & Aktifitas & $\begin{array}{c}\text { Penataan } \\
\text { Perabot } \\
(\text { perilaku) }\end{array}$ & $\begin{array}{c}\text { Penghawaan } \\
\text { (perilaku) }\end{array}$ & $\begin{array}{c}\text { Pencahayaan } \\
\text { (perilaku })\end{array}$ \\
\hline \multirow[t]{4}{*}{ RK 8} & $\begin{array}{l}\text { Ruang } \\
\text { Tamu \& } \\
\text { Ruang } \\
\text { Keluarga }\end{array}$ & $\begin{array}{l}\text { Menerima } \\
\text { tamu, } \\
\text { menonton } \\
\text { TV. }\end{array}$ & $\begin{array}{l}\text { Duduk di kursi } \\
\text { tanpa meja, } \\
\text { menggelar } \\
\text { tikar }\end{array}$ & $\begin{array}{ll}\text { Duduk di } & \text { dekat } \\
\text { pintu } & \text { yang } \\
\text { terbuka } & \end{array}$ & Tidak ada \\
\hline & $\begin{array}{l}\text { Ruang } \\
\text { Tidur }\end{array}$ & $\begin{array}{l}\text { Tidur, } \\
\text { istirahat }\end{array}$ & $\begin{array}{l}\text { Ruang tidur } 1 \text { : } \\
\text { di tempat } \\
\text { tidur.Ruang } \\
\text { tidur } 2 \text { : kasur } \\
\text { di lantai }\end{array}$ & $\begin{array}{lr}\text { Tidur di } & \text { dekat } \\
\text { jendela } & \text { dan } \\
\text { pintu } & \text { selalu } \\
\text { terbuka } & \end{array}$ & Tidak ada \\
\hline & Dapur & $\begin{array}{l}\text { Memasak, } \\
\text { membuat } \\
\text { minuman. }\end{array}$ & $\begin{array}{l}\text { Berdiri, } \\
\text { sedangkan saat } \\
\text { memasak } \\
\text { dilakukan } \\
\text { dengan } \\
\text { jongkon atau } \\
\text { memakai } \\
\text { dingklik. }\end{array}$ & Tidak ada & Tidak ada \\
\hline & $\begin{array}{l}\text { Tempat } \\
\text { Kerja }\end{array}$ & $\begin{array}{l}\text { Membuat } \\
\text { keramik }\end{array}$ & $\begin{array}{l}\text { Dengan } \\
\text { dingklik }\end{array}$ & Tidak ada & Tidak ada \\
\hline \multirow[t]{3}{*}{ RK 9} & $\begin{array}{l}\text { Ruang } \\
\text { Tamu \& } \\
\text { Ruang } \\
\text { Keluarga }\end{array}$ & $\begin{array}{l}\text { Menerima } \\
\text { tamu } \\
\text { (jarang), } \\
\text { tidur (ibu) }\end{array}$ & $\begin{array}{lr}\text { Tidur } & \text { di } \\
\text { amben, untuk } \\
\text { tempat pakaian } \\
\text { yang } \\
\text { disetrika. }\end{array}$ & $\begin{array}{l}\text { Melepas baju } \\
\text { bagi laki-laki. }\end{array}$ & Tidak ada \\
\hline & $\begin{array}{l}\text { Ruang } \\
\text { Tidur }\end{array}$ & tidur & $\begin{array}{l}\text { Tidur di kasur } \\
\text { beralas tikar }\end{array}$ & $\begin{array}{l}\text { Melepas baju } \\
\text { (laki-laki), } \\
\text { tidur dengan } \\
\text { pintu terbuka }\end{array}$ & Tidak ada \\
\hline & $\begin{array}{l}\text { Dapur \& } \\
\text { tempat } \\
\text { kerja }\end{array}$ & $\begin{array}{l}\text { Memasak } \\
\text { dan } \\
\text { membuat } \\
\text { keramik }\end{array}$ & $\begin{array}{l}\text { Jongkok, } \\
\text { duduk } \\
\text { dingklik }\end{array}$ & $\begin{array}{l}\text { Melepas baju } \\
\text { (laki-laki) }\end{array}$ & Tidak ada \\
\hline \multirow[t]{3}{*}{$\mathrm{RK} 10$} & $\begin{array}{l}\text { Ruang } \\
\text { Tamu \& } \\
\text { Ruang } \\
\text { Keluarga }\end{array}$ & $\begin{array}{l}\text { Menerima } \\
\text { tamu, } \\
\text { menonton } \\
\text { TV }\end{array}$ & $\begin{array}{l}\text { Menggelar } \\
\text { tikar }\end{array}$ & $\begin{array}{lr}\text { Memakai } & \text { kaos } \\
\text { tipis, } & \text { duduk } \\
\text { dekat } & \text { pintu } \\
\text { yang } & \text { selalu } \\
\text { terbuka } & \\
\end{array}$ & Tidak ada \\
\hline & $\begin{array}{l}\text { Ruang } \\
\text { Tidur }\end{array}$ & $\begin{array}{l}\text { Tidur, } \\
\text { istirahat }\end{array}$ & $\begin{array}{l}\text { Tidur } \\
\text { tempat tidur } \\
\text { (ruang tidur } 1 \text { ), } \\
\text { kasur dengan } \\
\text { alas } \\
\text { (ruang tidur } 2 \text { ) } \\
\end{array}$ & $\begin{array}{lr}\text { Tidur } & \text { dekat } \\
\text { pintu } & \text { dan } \\
\text { jendela } & \end{array}$ & Tidak ada \\
\hline & Dapur & Memasak & $\begin{array}{l}\text { Jongkok } \\
\text { menggunakan } \\
\text { alas kayu. }\end{array}$ & Tidaka ada & Tidak ada \\
\hline
\end{tabular}


Tabel 2. Adjustment

\begin{tabular}{|c|c|c|c|c|}
\hline $\begin{array}{l}\text { Rumah } \\
\text { Kasus }\end{array}$ & Ruang & $\begin{array}{l}\text { Penataan } \\
\text { Perabot } \\
\text { (fisik) }\end{array}$ & $\begin{array}{l}\text { Penghawaan } \\
\text { (fisik) }\end{array}$ & $\begin{array}{c}\text { Pencahayaan } \\
\text { (fisik) }\end{array}$ \\
\hline \multirow[t]{3}{*}{$\begin{array}{ll}\mathrm{RK} & 1\end{array}$} & $\begin{array}{l}\text { Ruang Tamu } \\
\& \quad \text { Ruang } \\
\text { Keluarga }\end{array}$ & $\begin{array}{l}\text { Ruang dijadikan } \\
\text { tempat memarkir } \\
\text { motor \& sepeda. }\end{array}$ & $\begin{array}{l}\text { Membuka pintu } \\
\text { belakang dan pintu } \\
\text { tembus untuk } \\
\text { mendapatkan } \\
\text { cross ventilation. }\end{array}$ & $\begin{array}{l}\text { Tidak memasang } \\
\text { kain pada jendela, } \\
\text { menyalakan lampu } \\
\text { pada malam hari }\end{array}$ \\
\hline & Ruang Tidur & $\begin{array}{lr}\text { Kasur } & \text { busa } \\
\text { disandarkan } & \text { di } \\
\text { dinding, tikar tetap } \\
\text { tergelar. }\end{array}$ & $\begin{array}{l}\text { Pintu terbuka pada } \\
\text { siang hari. }\end{array}$ & $\begin{array}{l}\text { Menutupi jendela } \\
\text { dengan kain supaya } \\
\text { tidak silau, } \\
\text { memasang genteng } \\
\text { kaca, menyalakan } \\
\text { lampu pada malam } \\
\text { hari. }\end{array}$ \\
\hline & $\begin{array}{l}\text { Dapur } \\
\text { Tempat } \\
\text { Kerja }\end{array}$ & $\begin{array}{l}\text { Menyesuaikan } \\
\text { dengan keluasan } \\
\text { ruang. } \\
\text { Tidak ada }\end{array}$ & $\begin{array}{l}\text { Tidak terdapat } \\
\text { daun pintu. } \\
\text { Membuka pintu }\end{array}$ & $\begin{array}{l}\text { Tidak terdapat daun } \\
\text { pintu. } \\
\text { Membuka pintu }\end{array}$ \\
\hline \multirow[t]{4}{*}{ RK 2} & $\begin{array}{l}\text { Ruang Tamu } \\
\& \quad \text { Ruang } \\
\text { Keluarga }\end{array}$ & $\begin{array}{lr}\text { Sebagai } & \text { tempat } \\
\text { menyimpan } & \\
\text { peralatan } & \text { dan } \\
\text { sepeda. Pintu } & \text { selalu tertutup. }\end{array}$ & $\begin{array}{l}\text { Membuka jendela } \\
\text { "krepyak". }\end{array}$ & $\begin{array}{l}\text { Memasang kain } \\
\text { pada jendela depan, } \\
\text { menyalakan lampu } \\
\text { pada malam hari }\end{array}$ \\
\hline & Ruang Tidur & $\begin{array}{l}\text { Tempat tidur } \\
\text { sebagai tempat } \\
\text { menyimpan } \\
\text { pakaian yang } \\
\text { sudah kering dan } \\
\text { siap disetrika }\end{array}$ & $\begin{array}{l}\text { Membuka pintu } \\
\text { (RT 2), menutup } \\
\text { dengan kain (RT } \\
\text { 1). }\end{array}$ & $\begin{array}{l}\text { membuka pintu ( } \\
\text { RT 2), menyalakan } \\
\text { lampu (RT 1,2). }\end{array}$ \\
\hline & Dapur & $\begin{array}{lr}\text { meletakkan } & \\
\text { peralatan } & \text { dapur } \\
\text { dekat } & \text { dengan } \\
\text { sumur } & \end{array}$ & Tidak ada & Tidak ada \\
\hline & $\begin{array}{l}\text { Tempat } \\
\text { Kerja }\end{array}$ & $\begin{array}{l}\text { Dingklik dan } \\
\text { perbot diletakkan } \\
\text { pada daerah yang } \\
\text { tidak terkena sinar } \\
\text { matahari. }\end{array}$ & $\begin{array}{l}\text { memasang dinding } \\
\text { pada satu sisi }\end{array}$ & Tidak ada \\
\hline
\end{tabular}




\begin{tabular}{|c|c|c|c|c|}
\hline $\begin{array}{l}\text { Rumah } \\
\text { Kasus }\end{array}$ & Ruang & $\begin{array}{l}\text { Penata an } \\
\text { Perabot } \\
\text { (fisik) }\end{array}$ & $\begin{array}{c}\text { Penghawa an } \\
\text { (fisik) }\end{array}$ & $\begin{array}{c}\text { Pencahay aan } \\
\text { (fisik) }\end{array}$ \\
\hline \multirow[t]{3}{*}{ RK 3} & $\begin{array}{l}\text { Ruang } \\
\text { Tamu dan } \\
\text { Ruang } \\
\text { keluarga }\end{array}$ & $\begin{array}{lr}\text { Bangku berfungsi } \\
\text { ganda, } & \text { selain } \\
\text { menerima } & \text { tamu } \\
\text { juga } & \text { untuk } \\
\text { istirahat. } & \\
\end{array}$ & Pintu terbuka & $\begin{array}{l}\text { Menyalakan } \\
\text { lampu pada } \\
\text { malam hari. }\end{array}$ \\
\hline & Ruang Tidur & $\begin{array}{l}\text { Memakai kain } \\
\text { menggantikan } \\
\text { pintu, multiplex di } \\
\text { tempat tidur supaya } \\
\text { tidak terkena } \\
\text { serpihan batu bata } \\
\text { dan semen. } \\
\text { meletakkan perabot } \\
\text { memasak, tempat } \\
\text { menyimpan bumbu } \\
\text { dan kursi yang } \\
\text { difungsikan sebagai } \\
\text { meja saling } \\
\text { berdekatan }\end{array}$ & $\begin{array}{l}\text { Membuat dinding } \\
\text { dari gedheg. }\end{array}$ & 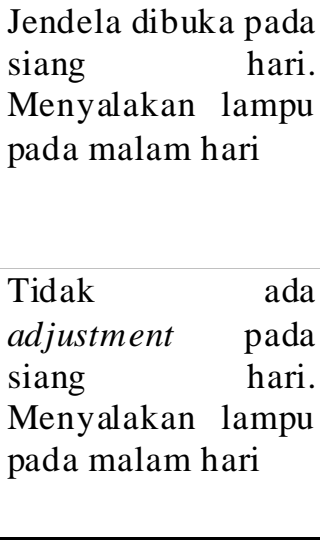 \\
\hline & $\begin{array}{l}\text { Tempat } \\
\text { Kerja }\end{array}$ & Tidak ada & Tidak ada & Tidak ada \\
\hline \multirow[t]{3}{*}{ RK 4} & $\begin{array}{l}\text { Ruang } \text { Tamu } \\
\& \quad \text { Ruang } \\
\text { Keluarga }\end{array}$ & $\begin{array}{l}\text { Tidak ada } \\
\text { fasilitas } \\
\text { menerima tamu, }\end{array}$ & $\begin{array}{l}\text { Menutup pintu saat } \\
\text { ada pembakaran } \\
\text { keramik, }\end{array}$ & $\begin{array}{l}\text { Memasang genteng } \\
\text { kaca, Menyalakan } \\
\text { lampu pada malam } \\
\text { hari }\end{array}$ \\
\hline & Ruang Tidur & $\begin{array}{lr}\text { Box } & \text { bayi } \\
\text { diletakkan di ruang } \\
\text { keluarga, kasur } \\
\text { busa disandarkan } \\
\text { jika tidak } \\
\text { digunakan. }\end{array}$ & $\begin{array}{ll}\text { Pintu } & \text { selalu } \\
\text { terbuka } & \end{array}$ & $\begin{array}{l}\text { Memasang } \\
\text { bovenlicht, }\end{array}$ \\
\hline & $\begin{array}{l}\text { Tempat } \\
\text { Kerja } \\
\end{array}$ & \begin{tabular}{lr}
\multicolumn{3}{l}{ Meletakkan } \\
kompor di & bawah \\
(di & lantai), \\
meletakkan & meja \\
untuk membuat \\
minuman & dan \\
menyiapkan & \\
makanan & dekat \\
dengan rak & piring \\
dan gelas. & \\
Tidak ada &
\end{tabular} & $\begin{array}{l}\text { Membuka pintu } \\
\text { dapur. }\end{array}$ & \begin{tabular}{lr} 
Tidak & ada \\
adjustment & pada \\
siang & hari. \\
Menyalakan lampu & \multicolumn{2}{l}{ pada malam hari }
\end{tabular} \\
\hline RK 5 & $\begin{array}{l}\text { Ruang Tamu } \\
\& \quad \text { Ruang } \\
\text { Keluarga }\end{array}$ & $\begin{array}{l}\text { Meletakkan rak } \\
\mathrm{TV}, \quad \text { almari } \\
\text { pakaian } \\
\text { berdekatan }\end{array}$ & Meletakkan fan & $\begin{array}{lr}\text { Tidak } & \text { ada } \\
\text { adjustment } & \text { pada } \\
\text { siang } & \text { hari. } \\
\text { Menyalakan lampu } & \text { lada malam hari }\end{array}$ \\
\hline
\end{tabular}




\begin{tabular}{|c|c|c|c|c|}
\hline $\begin{array}{c}\text { Rumah } \\
\text { Kasus }\end{array}$ & Ruang & $\begin{array}{c}\text { Penata an } \\
\text { Perabot } \\
\text { (fisik) }\end{array}$ & $\begin{array}{c}\text { Pengha waan } \\
\text { (fisik) }\end{array}$ & $\begin{array}{c}\text { Pencahay aan } \\
\text { (fisik) }\end{array}$ \\
\hline & Ruang Tidur & $\begin{array}{l}\text { Hanya meletakkan } \\
\text { tempat tidur di } \\
\text { ruang tidur tanpa } \\
\text { ada perabot lain. }\end{array}$ & $\begin{array}{l}\text { Membuka pintu } \\
\text { dan jendela }\end{array}$ & $\begin{array}{l}\text { Tidak memasang } \\
\text { kain pada jendela } \\
\text { dan pintu. Pada } \\
\text { malam hari } \\
\text { pengguna ruang } \\
\text { menyalakan lampu }\end{array}$ \\
\hline & Dapur & $\begin{array}{l}\text { meletakkan meja } \\
\text { tempat } \\
\text { menghidangkan } \\
\text { makanan dengan } \\
\text { menyiapkan } \\
\text { minuman saling } \\
\text { berdekatan }\end{array}$ & $\begin{array}{l}\text { meletakkan } \\
\text { perabot dekat } \\
\text { dengan roaster. }\end{array}$ & $\begin{array}{l}\text { Tidak ada } \\
\text { adjustment pada } \\
\text { siang hari. } \\
\text { Menyalakan lampu } \\
\text { pada malam hari }\end{array}$ \\
\hline & $\begin{array}{l}\text { Tempat } \\
\text { Kerja }\end{array}$ & Tidak ada & Tidak ada & Tidak ada \\
\hline \multirow[t]{4}{*}{ RK 6} & $\begin{array}{l}\text { Ruang } \\
\text { Tamu \& } \\
\text { Ruang } \\
\text { Keluarga }\end{array}$ & $\begin{array}{l}\text { Meletakkan meja } \\
\text { dan kursi tamu } \\
\text { berdekatan dengan } \\
\text { TV, Meja tamu } \\
\text { dijadikan tempat } \\
\text { meletakkan TV. }\end{array}$ & $\begin{array}{l}\text { Membuka pintu, } \\
\text { kecuali malam } \\
\text { hari }\end{array}$ & $\begin{array}{l}\text { Tidak ada } \\
\text { adjustment pada } \\
\text { siang hari. } \\
\text { Menyalakan lampu } \\
\text { pada malam hari }\end{array}$ \\
\hline & Ruang Tidur & Tidak ada & $\begin{array}{l}\text { menghidupkan } \\
\text { fan, membuka } \\
\text { pintu dan jendela. }\end{array}$ & $\begin{array}{l}\text { Tidak ada } \\
\text { adjustment pada } \\
\text { siang } \\
\text { Menyalakan lampu } \\
\text { pada malam hari }\end{array}$ \\
\hline & Dapur & $\begin{array}{l}\text { Meletakkan meja } \\
\text { persiapan dan rak } \\
\text { piring berdekatan }\end{array}$ & Tidak ada & $\begin{array}{l}\text { Tidak ada } \\
\text { adjustment pada } \\
\text { siang hari. } \\
\text { Menyalakan lampu } \\
\text { pada malam hari }\end{array}$ \\
\hline & $\begin{array}{l}\text { Tempat } \\
\text { Kerja }\end{array}$ & Tidak ada & Tidak ada & Tidak ada \\
\hline \multirow[t]{2}{*}{ RK 7} & $\begin{array}{l}\text { Ruang } \\
\text { Tamu \& } \\
\text { Ruang } \\
\text { Keluarga }\end{array}$ & Tidak ada & $\begin{array}{l}\text { membuat pintu } \\
\text { dan jendela } \\
\text { sebanyak- } \\
\text { banyaknya, }\end{array}$ & $\begin{array}{l}\text { membuat pintu } \\
\text { dan jendela } \\
\text { sebanyak- } \\
\text { banyaknya serta } \\
\text { memasang } \\
\text { genteng kaca, } \\
\text { Menyalakan lampu } \\
\text { pada malam hari }\end{array}$ \\
\hline & Ruang Tidur & Tidak ada & Pintu yang dibuka & $\begin{array}{l}\text { Pemasangan } \\
\text { genteng kaca dan } \\
\text { bovenlicht. } \\
\text { Menyalakan lampu } \\
\text { pada malam hari }\end{array}$ \\
\hline
\end{tabular}




\begin{tabular}{|c|c|c|c|c|}
\hline $\begin{array}{l}\text { Rumah } \\
\text { Kasus }\end{array}$ & Ruang & $\begin{array}{l}\text { Penataan } \\
\text { Perabot } \\
\text { (fisik) }\end{array}$ & $\begin{array}{c}\text { Pengha waa n } \\
\text { (fisik) }\end{array}$ & $\begin{array}{c}\text { Pencahayaan } \\
\text { (fisik) }\end{array}$ \\
\hline & Dapur & $\begin{array}{l}\text { Penggunaan kursi } \\
\text { untuk tempat } \\
\text { kompor }\end{array}$ & $\begin{array}{l}\text { lubang-lubang } \\
\text { gedheg. }\end{array}$ & $\begin{array}{l}\text { pintu yang } \\
\text { terbuka, } \\
\text { Menyalakan lampu } \\
\text { pada malam hari }\end{array}$ \\
\hline & $\begin{array}{l}\text { Tempat } \\
\text { Kerja }\end{array}$ & $\begin{array}{lr}\text { Meletakkan } & \\
\text { dingklik } & \text { dan } \\
\text { perabot } & \text { pada } \\
\text { daerah yang } & \text { tidak } \\
\text { terkena } & \text { sinar } \\
\text { matahari } & \\
\end{array}$ & $\begin{array}{l}\text { Memasang tanaman } \\
\text { dengan digantung }\end{array}$ & $\begin{array}{l}\text { Menyalakan lampu } \\
\text { pada malam hari } \\
\text { karena } \\
\text { malam hari berfungsi } \\
\text { sebagai teras. }\end{array}$ \\
\hline \multirow[t]{4}{*}{ RK 8} & $\begin{array}{l}\text { Ruang Tamu } \\
\& \quad \text { Ruang } \\
\text { Keluarga }\end{array}$ & $\begin{array}{lr}\text { Meletakkan } & \text { kursi } \\
\text { tamu dekat } & \text { de pintu, } \\
\text { dengan rak } \\
\text { meletakkan ran } \\
\text { TV dekat dengan } \\
\text { kursi tamu. }\end{array}$ & $\begin{array}{lr}\text { Membuka } & \text { kaca } \\
\text { jendela } & \text { dan } \\
\text { pemasangan roaster. } & \text { Menutup kaca ruang } \\
\text { Menu dengan } & \text { tamu sinar } \\
\text { multiplex saat sinat } \\
\text { matahari sore yang } \\
\text { panas masuk ke } \\
\text { dalam ruang tamu. }\end{array}$ & $\begin{array}{l}\text { Menutup kaca ruang } \\
\text { tamu dengan } \\
\text { multiplex saat sinar } \\
\text { matahari sore yang } \\
\text { panas masuk ke } \\
\text { dalam ruang tamu. } \\
\text { Menyalakan lampu } \\
\text { pada malam hari }\end{array}$ \\
\hline & Ruang Tidur & $\begin{array}{l}\text { 1. RT } 1 \text { : } \\
\text { meletakkan } \\
\text { tempat tidur } \\
\text { dekat dengan } \\
\text { meja saji, ditata } \\
\text { statis } \\
\text { 2. RT 2 : hanya } \\
\text { meletakkan } \\
\text { kasur busa saja. }\end{array}$ & $\begin{array}{l}\text { Membuka jendela } \\
\text { dan pintu, } \\
\text { memasang roaster, } \\
\text { meletakkan tempat } \\
\text { tidur dan kasur } \\
\text { dekat dengan } \\
\text { jendela. }\end{array}$ & $\begin{array}{l}\text { Tidak memasang } \\
\text { kain pada jendela, } \\
\text { Menyalakan lampu } \\
\text { pada malam hari }\end{array}$ \\
\hline & Dapur & $\begin{array}{l}\text { Membuat sendiri } \\
\text { meja racik dan } \\
\text { rak piring }\end{array}$ & Tidak ada. & $\begin{array}{l}\text { Tidak ada adjustment } \\
\text { pada siang hari. } \\
\text { Menyalakan lampu } \\
\text { pada malam hari }\end{array}$ \\
\hline & $\begin{array}{l}\text { Tempat } \\
\text { Kerja }\end{array}$ & $\begin{array}{lr}\text { Meletakkan } & \\
\text { dingklik } & \text { dan } \\
\text { perbot } & \text { pada } \\
\text { daerah yang } & \text { tidak } \\
\text { terkena } & \text { sinar } \\
\text { matahari } & \end{array}$ & $\begin{array}{l}\text { Memasang dinding } \\
\text { dari multiplex } \\
\text { untuk menghindari } \\
\text { sinar matahari } \\
\text { sehingga } \\
\text { tidak panas. }\end{array}$ & $\begin{array}{l}\text { Memasang dinding } \\
\text { dari multiplex untuk } \\
\text { menghindari sinar } \\
\text { matahari pada waktu } \\
\text { kerja, Menyalakan } \\
\text { lampu pada malam } \\
\text { hari saat berfungsi } \\
\text { sebagai teras. }\end{array}$ \\
\hline RK 9 & $\begin{array}{l}\text { Ruang Tamu } \\
\& \quad \text { Ruang } \\
\text { Keluarga }\end{array}$ & $\begin{array}{l}\text { Amben tersebut } \\
\text { menjadi } \\
\text { multifungsi yaitu } \\
\text { sebagai tempat } \\
\text { pakaian dan tempat } \\
\text { tidur istri, terdapat } \\
\text { multiplex untuk } \\
\text { menghindari } \\
\text { serpihan semen } \\
\text { jatuh ke amben. }\end{array}$ & $\begin{array}{l}\text { Membuka pintu } \\
\text { pada siang hari }\end{array}$ & $\begin{array}{l}\text { Memasang kain pada } \\
\text { jendela untuk } \\
\text { mengurangi cahaya } \\
\text { lang sung masuk ke } \\
\text { ruang tersebut, } \\
\text { Menyalakan lampu } \\
\text { pada malam hari }\end{array}$ \\
\hline
\end{tabular}




\begin{tabular}{|c|c|c|c|c|}
\hline $\begin{array}{l}\text { Rumah } \\
\text { Kasus }\end{array}$ & Ruang & $\begin{array}{l}\text { Penataan } \\
\text { Perabot } \\
\text { (fisik) }\end{array}$ & $\begin{array}{l}\text { Penghawaan } \\
\text { (fisik) }\end{array}$ & $\begin{array}{c}\text { Pencahayaan } \\
\text { (fisik) }\end{array}$ \\
\hline & Ruang Tidur & $\begin{array}{l}\text { Hanya } \\
\text { meletakkan kasur } \\
\text { saja. }\end{array}$ & $\begin{array}{ll}\text { Membuka pintu } \\
\text { kamar pada } & \text { siang } \\
\text { hari } & \end{array}$ & $\begin{array}{l}\text { Pemakaian kain } \\
\text { pada jendela. } \\
\text { Menyalakan lampu } \\
\text { pada malam hari }\end{array}$ \\
\hline & $\begin{array}{l}\text { Dapur \& } \\
\text { tempat kerja }\end{array}$ & \begin{tabular}{lr}
\multicolumn{2}{l}{ Meletakkan } \\
dingklik dan \\
perabot pada \\
daerah yang tidak \\
terkena sinar \\
matahari.
\end{tabular} & Tidak ada & \begin{tabular}{lr} 
Tidak & ada \\
adjustment & pada \\
siang & hari. \\
Menyalakan & lampu \\
\multicolumn{2}{l}{ pada malam hari }
\end{tabular} \\
\hline RK 10 & $\begin{array}{l}\text { Ruang } \text { Tamu } \\
\& \quad \text { Ruang } \\
\text { Keluarga }\end{array}$ & Menggelar tikar & $\begin{array}{lr}\text { Membuka } & \text { pintu } \\
\text { depan } & \text { dan } \\
\text { belakang } & \text { pada } \\
\text { siang hari } & \text { supaya } \\
\text { udara bisa } & \text { masuk } \\
\text { secara } & \text { cross } \\
\text { ventilation } & \end{array}$ & $\begin{array}{l}\text { Tidak memasang } \\
\text { kain pada jendela }\end{array}$ \\
\hline & Ruang Tidur & $\begin{array}{l}\text { Tempat tidur } \\
\text { selain berfungsi } \\
\text { sebagai tempat } \\
\text { untuk tidur juga } \\
\text { untuk tempat } \\
\text { pakaian yang } \\
\text { siap disetrika, } \\
\text { memasang } \\
\text { multiplex }\end{array}$ & $\begin{array}{l}\text { Membuka jendela } \\
\text { pada siang hari. }\end{array}$ & $\begin{array}{l}\text { Tidak memasang } \\
\text { kain di jendela, } \\
\text { Menyalakan lampu } \\
\text { pada malam hari }\end{array}$ \\
\hline & $\begin{array}{l}\text { Dapur \& } \\
\text { Tempat } \\
\text { Kerja }\end{array}$ & $\begin{array}{lr}\text { Menata dapur } \\
\text { dengan seadanya, } \\
\text { asal } \\
\text { memasak. }\end{array}$ & \begin{tabular}{lr}
\multicolumn{2}{l}{ Tempat kerja yang } \\
dindingnya & terbuat \\
dari & anyaman \\
bambu & untuk \\
memenuhi & fungsi \\
sebagai & daput \\
dibuat & sekat \\
dengan & bahan \\
multiplex & supaya \\
angin & tidak \\
menggangu & \\
jalannya & proses \\
memasak. &
\end{tabular} & $\begin{array}{lr}\text { Tidak } & \text { ada } \\
\text { adjustment } & \text { pada } \\
\text { siang } & \text { hari. } \\
\text { Menyalakan } & \text { lampu } \\
\text { pada malam hari }\end{array}$ \\
\hline
\end{tabular}


Penyesuaian diri ini mengakibatkan perubahan pada diri seseorang tersebut atau sebaliknya, seseorang akan merubah lingkungan huniannya sesuai dengan kebutuhannya. Perubahan perilaku akibat penyesuaian tersebut kemungkinan akan terjadi dalam rumah baru tersebut. Perubahan tersebut dapat disebabkan oleh tempat maupun lingkungan yang berbeda dari tempat tinggal sebelumnya. Tekanantekanan meningkatkan energi dalam dirinya sehingga ia harus mengadakan penyesuaian diri (coping behavior) atau menyesuaikan lingkungan untuk kondisi dirinya. Penyesuaian antara individu dengan lingkungan dinamai adaptasi dan bila ada penyesuaian keadaan lingkungan untuk dirinya secara individu dinamai adjustment.

Hasil penelitian menunjukkan bahwa semua penduduk mengalami adaptasi dan adjustment pada rumah tinggal bantuan pasca gempa. Penyesuaian tersebut paling banyak pada aspek termal (mengatasi panas ruang) pada siang hari yaitu dari aspek fisik dan perilaku, penggunaan perabot yang menjadi perabot multifungsi dan penggunaan ruang menjadi ruang multi fungsi.

\section{DAFTAR PUSTAKA}

Ching, Francis D.K. 2000. Arsitektur: Bentuk, Ruang dan Tatanan. terjemahan Nurahma Tresani Harwadi. Jakarta: Penerbit Erlangga.

Gustami, S.P. 1985. Pola Hidup dan Produk Kerajinan Keramik Kasongan Yogyakarta (Laporan Penelitian). Yogyakarta: Lembaga Penelitian ISI Yogyakarta,

Heimstra, N.W. \& McFarling, L.H. 1974. Environmental Psychology. Monterey: Brooks/Cole Publishing Company.

Hester, Randolph T. 1975. Neighborhood Space. Stroudsburg: Dowden, Hudchinson \& Ross.

http://id.wikipedia.org/wiki/Gempa_bumi_Yo gyakarta_Mei_2006
Lang, Jon. 1974. Designing for Human Behavior, Architecture and The Behavioral Sciences. Stroudsburg: Dowden, Hudchinson \& Ross.

Lantrip, David B. 1993. Environmental Constraint of Human Movement: A Case Study of The Effect on Office Worker Environmental Satisfaction and Self-rate Productifity (Disertation for Doctor of Philosophy). Ann Arbor: The University of Michigan.

Porteous, J. Douglas. 1977. Environmental and Behavior: Planning and Everyday Urban Life. London: Addison-Wesley Publishing Company.

Sarwono, Sarlito W. 1992. Psikologi Lingkungan. Jakarta: Grasindo.

Sukmana, Oman. 2003. Dasar-dasar Psikologi Lingkungan. Malang: Bayu Media \& UMM Press. 
LUNTAS NG | VOL.2 | EDISI 3 | 2008 ISSN 1978-0702 